\title{
Orthothermographies and 3D modeling as potential tools in ice caves studies: the Peña Castil Ice Cave (Picos de Europa, Northern Spain)
}

Fernando Berenguer-Sempere ${ }^{1 *}$, Manuel Gómez-Lende ${ }^{2, *}$, Enrique Serrano $^{2}$, and José Juan de Sanjosé-Blasco ${ }^{1}$

${ }^{1}$ Departamento de Expresión Gráfica - Escuela Politécnica, Universidad de Extremadura, Cáceres

${ }^{2}$ Departamento de Geografia, Universidad de Valladolid, Valladolid

\begin{abstract}
Currently there are many studies focused on the investigation of climatic and glaciological condition of ice caves. Here we present another way to address these studies, applying some methods already used in fields other than geomorphology. The versatility and accuracy provided by the use of modern topography and thermography techniques, using Terrestrial Laser Scanner and current thermographic cameras- and the creation of 3D thermographic models and orthothermographies derived from them - is shown to be a useful tool as it is difficult to obtain data from fieldwork and traditional methods used in caves. This paper presents the potential uses of combined TLS and thermographic techniques for monitoring some important climatological parameters in the sensitive periglacial environment of the Iberian Atlantic high mountains: Peña Castil Ice Cave (Picos de Europa, Northern Spain). A systematic application of such combined technologies to these kind of caves, is expected to contribute to a quantitative and concise characterization of the evolution of the ice as shown by the results of this study.
\end{abstract}

Keywords: orthothermographies; infrared thermography; TLS 3D model; ice caves; Picos de Europa

Received 18 March 2013; Revised 1 August 2013; Accepted 26 November 2013

Citation: Berenguer Sempere F., Gómez-Lende M., Serrano E. and de Sanjosé-Blasco J.J., 2014. Orthothermographies and 3D models as potential tools in ice cave studies: the Peña Castil Ice Cave (Picos de Europa, Northern Spain). International Journal of Speleology, 43 (1), 35-43. Tampa, FL (USA) ISSN 0392-6672 http://dx.doi.org/10.5038/1827-806X.43.1.4

\section{INTRODUCTION}

Thermography is a technique that can measure temperatures from a distance without needing physical contact with the object being studied by sensing the infrared radiation of the electromagnetic spectrum (Melgosa, 2011). The temperature measurement is current as it can be measured while the object is displayed on the camera screen. If the object changes, the camera shows the change immediately, without inertia. Temperature can be measured at two or more points simultaneously on the same object allowing an image of temperature to be composed. The thermal image, unlike the real image, is an image of thermal radiation, not of the temperature distribution captured by the camera. The difference in radiation intensities are not translated into temperature differences. This means that the object of study can be at the same temperature, but with different emissivities. Therefore, the thermal image will appear with a contrast reflected in the color palette that may has appear as different temperatures. Qualitative and a quantitative analysis can be done of the same infrared image can be done. Firstly, in the qualitative analysis, the thermal image is analyzed to distinguish an anomaly, locate it and assess the level of variation. Secondly, the quantitative analysis determines the temperature or temperatures of the anomalies detected (but, as mentioned, thermography does not allow a given surface temperature to be quantified). To overcome this disadvantage, it must be combined with 3D surveying techniques. The laser scanner is the most suitable for 3D surveying techniques, thanks to its simplicity, speed and accuracy. Thermographies overlap these techniques, providing metric information not previously available. From this point, the surface temperature or the temperature difference between two points may be quantified (Ergun et al., 2010).

Moreover, this measurement is made non-invasively (without contact, non-destructively), a fact that makes thermography a suitable technique for application in different disciplines related to the study of the 
cryosphere. They are of particular interest in cases such as ice caves, in which marginal ice morphologies are particularly sensitive to climatic variations (seasonal cryospeleothems, centimetric variations in ice levels, the length of the cold wavelength transmitted by the ice block or the precise description of its internal air and heat circulations, among others). Field conditions in caves are often complex being dark and with difficult access.

Some of the tools used in the present study, 3D Terrestrial Laser Scanner (3D TLS), have been used in previous studies to obtain topographies; realistic threedimensional models in non-frozen caverns (Canevese et al., 2008a, 2008b, 2009, 2011; Buchroithner \& Gaisecker, 2009; Roncat et al., 2011a; 2011b; Höfle et al., 2012; Santos Delgado et al., 2012). These tools have been used for developing high realistic three-dimensional models in ice caves, over the last few years and only in some important show caverns, (Milius \& Peters, 2012). All of these studies had different motives (heritage, touristic, archaeological, mining, etc), but never oriented towards the determination of cryomorphological dynamics and processes within them.

This paper presents a methodology to combine metric TLS with thermal data from the thermographic camera at the Peña Castil Ice Cave, Picos de Europa. The final experimental design arises from the topographic and thermographic study as scans and thermographic data are processed. This methodology aims to show its potential by the monitoring of essential climatic parameters and how these evolve in this type of cave, which would otherwise be very difficult to determine.

\section{STUDY AREA}

The Peña Castil Ice Cave is situated in the high periglacial mountain environment of the central massif of the Picos de Europa. This example of the Atlantic glaciokarst high mountain, Picos de Europa, is situated in the north of the Cantabrian Range (northern Spain) with a maximum altitude of $2648 \mathrm{~m}$ (Torrecerredo) (Fig. 1). The current morphodynamic of its highest landscape (above $1800 \mathrm{~m}$ ) is dominated by snow, cold and slope dynamics (González Trueba \& Serrano, 2010). It is a marginal periglacial and totally deglaciated landscape in which the entire perennial ice body takes on great relevance both at the surface (perennial snow and ice patches from the historical glaciers of the Little Ice Age), or below it (ice caves).

The Peña Castil Ice Cave is situated on the line of summits over the valley of the Duje, with its main entrance oriented to the east at $2095 \mathrm{~m}$. There are no other entrances known. Its horizontal development is small (72 $\mathrm{m}$ approx.), with a SSE-NNW orientation. Its depth is hidden by the ice body, and its upward development is unknown. The ice body is found in its two main rooms, which are accessed by a wide filled ramp of scree and snow for most of the year. Beyond these rooms, there is a small corridor whose floor is covered by different sized blocks, and which gives way to a final room, also with a floor with large blocks and completely free of ice. The lateral topographies of the main rooms indicate their downward continuity, but their closure by
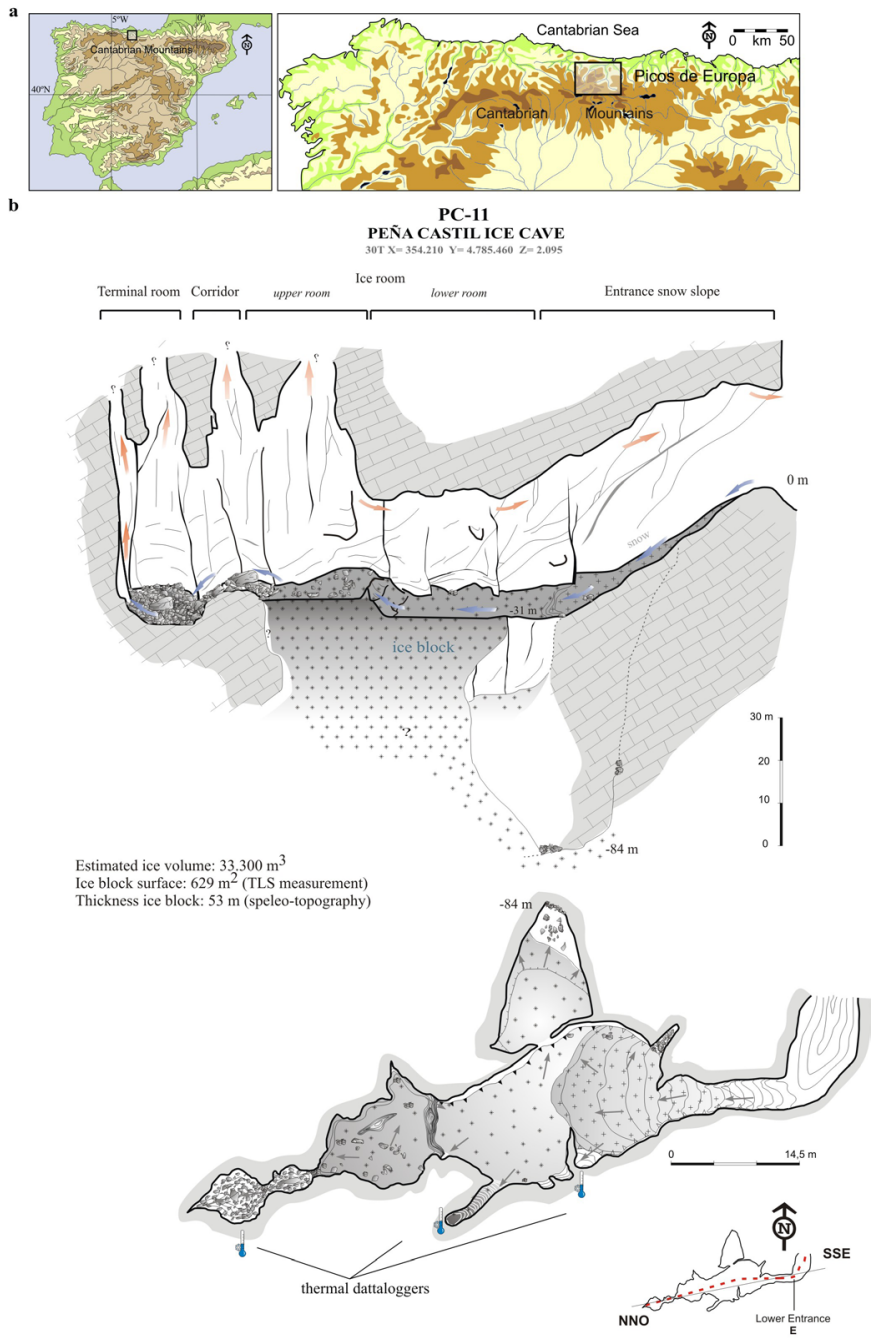

Fig. 1. a) Peña Castil Ice Cave location in Central massif of Picos de Europa (North Spain); b) Ice cave topography (ice block depth modified from Ogando, 1995). Coloured narrows show inside airflow and grey ones show ice flows.

the ice block has limited their exploration to $-84 \mathrm{~m}$ or less (Sánchez et al., 2011; Gómez-Lende et al., 2011; Gómez-Lende \& Serrano, 2012a, 2012b).

According to glacioclimatological criteria, Peña Castil Ice Cave is a static ice cave with firn and congelation ice, according to the Luetscher \& Jeannin classification (Luetscher \& Jeannin, 2004) with two main periods for dynamic ventilation of the air: open period, November-March, with heterothermal conditions; and closed period, May-September, with homothermal conditions inside the cave. Others months are transitional periods (Gómez-Lende \& Serrano 2012a, 2012b) (Fig. 2).

\section{EQUIPMENT AND METHODOLOGY}

\section{Equipment}

The thermographic camera FLIR SC660 was used, which measures temperature in a range from -40 to $1500^{\circ} \mathrm{C}$ with a thermal resolution of $0,03^{\circ} \mathrm{C}$. The IR resolution was $640 \times 480$ pixels and angular resolution (IFOV) 0,65 mrad. The field of vision (FOV) used was $24^{\circ}$ on the horizontal plane and $18^{\circ}$ on the vertical. The software used for image treatment was the ThermaCAM Researcher Pro 2.10 and to calibrate the metric camera, the program Photomodeler Pro v5 was applied. 


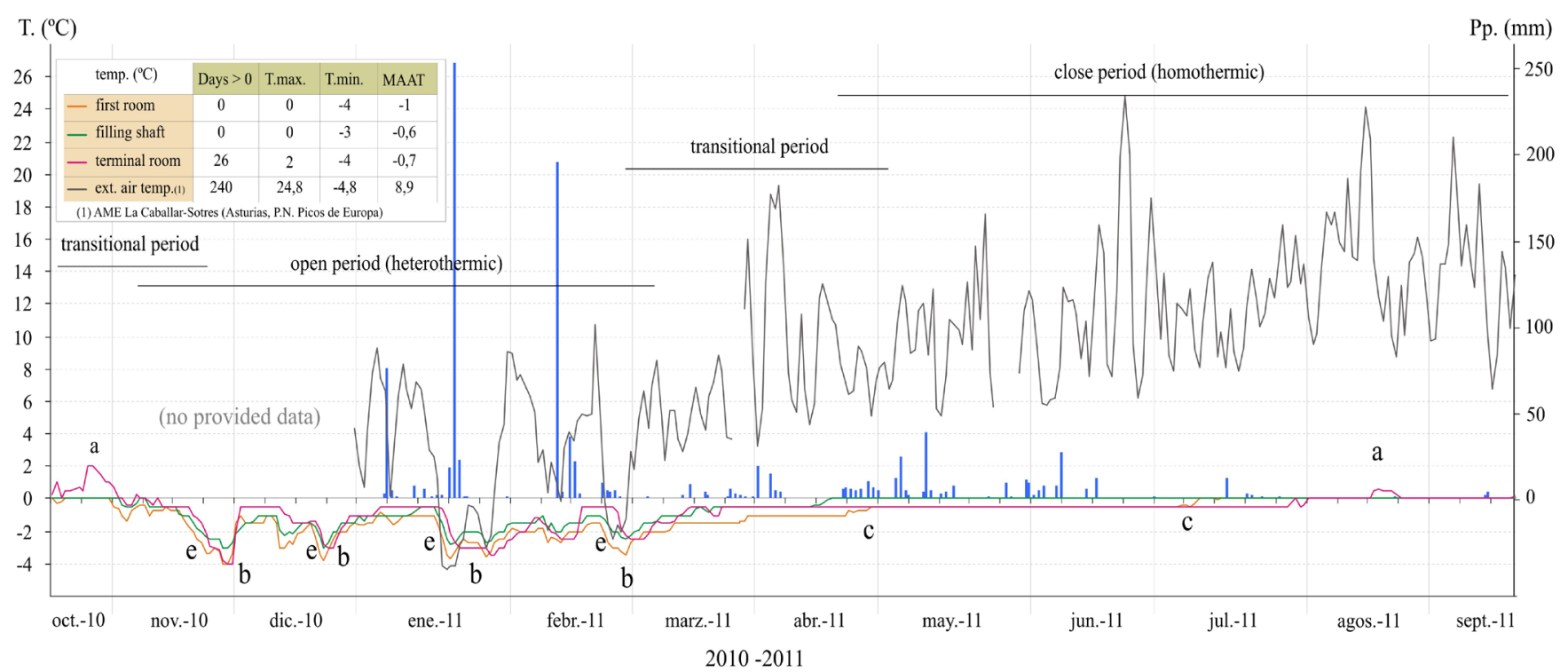

Fig. 2. Thermal regime in Peña Castil Ice Cave (Gomez-Lende et al., 2012a). Different correlations exist between air cave temperature and exterior air temperature.

A 3D TLS Leica ScanStation C10 was used for topographical survey (Fig. 3). It measures distances within a range from 1.5 to $300 \mathrm{~m}$ with nominal precision of $+/-6 \mathrm{~mm}$ at a distance of $50 \mathrm{~m}$ with normal illumination and under conditions of reflectivity. The vertical field of vision has a range of $270^{\circ}$ sexagesimal and $360^{\circ}$ in the horizontal. The software used for the recording, alignment of clouds of points and data treatment was Leica Cyclone 7.3 (C).

The cave was monitored thermohygrometrically through the use of thermorecorders iButton DS1921G with thermal ranges between -40 and $+85^{\circ} \mathrm{C}$, a precision of $0.5^{\circ} \mathrm{C}$ with a programmable data collection of 1 to 255 minutes and synchronized with real time and capacity to record 2048 consecutive measurements. The hygrometric control was done by iButton Hygrochron DS1923 dataloggers for the measurement of temperature and humidity with a precision in humidity recording of up to $0.04 \%$ and a working thermal range from -20 to $+85^{\circ} \mathrm{C}$ and up to $100 \%$ of humidity. The precision range in the collection of temperatures was also of $0.5^{\circ} \mathrm{C}$ and a capacity of 8192 consecutive readings equidistant between them from 1 sec. up to 273 hours. This instrumentation was distributed through the interior of the ice cave recording its climatic behaviour
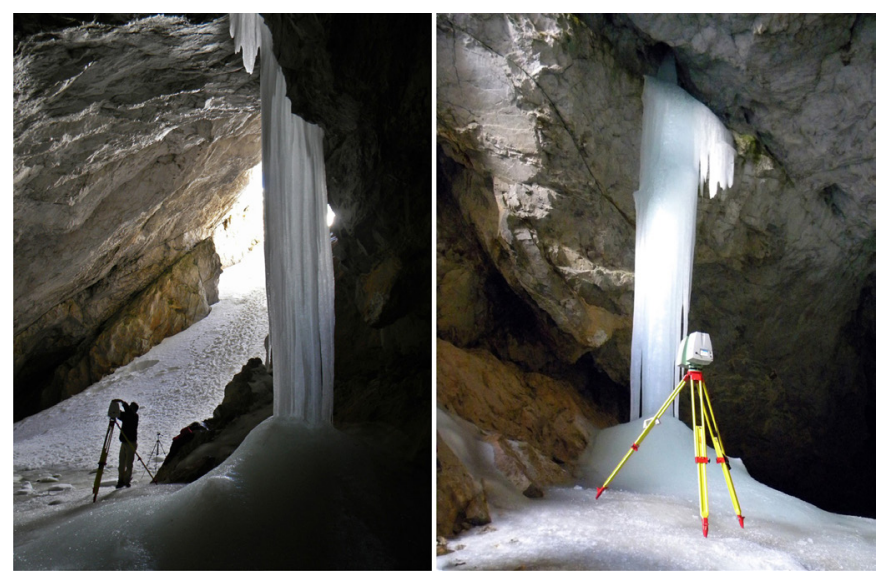

Fig. 3. TSL Leica ScanStation C10 3D placement in lower ice room. (fundamentally around its ice block) being a perfect complement for the check of the data obtained using the thermographic camera. In a later publication, we'11 correlate orthothermographies and 3D models from this paper (from November 2012 fieldwork), with data being recorded now (to be collected in November 2013).

\section{METHODOLOGY}

Orthoimages are in great demand in any application in which precise geometry is required. Moreover in this case, their metric quality is combined with the thermal detail of the thermographies to offer highly useful information for certain qualitative evaluations, such as thermal differences, materials, etc. (Bryan et al., 1999; Rodríguez-Gonzálvez et al., 2012). The technical procedure presented in this paper has been used in previous studies on energy efficiency in buildings (Lagüela et al., 2011). Their methodolgy has been applied in this study of Peña Castil Ice Cave.

The topographical and thermographical fieldwork was accomplished in November 2012, focusing on a preliminary characterization and to test the combination of this method inside the ice cave. November is a suitable time because it is the beginning of the open period where snow melts entirely and the ice block is free of snow (see Fig. 2). It enables a topographical survey of the ice with no snow interference. It also enables access to the cave more easily and in safety (avalanches are frequent in Picos de Europa during winter and spring).

\section{Thermographic survey}

The thermographies were taken of the desired area and in consideration of the focal length of the camera. In order to produce the panoramic image, all shots were taken on a tripod with a longitudinal overlap of at least $40 \%$. To avoid any bias in the data, it was necessary to take temperature and humidity data during the fieldwork by manual instruments (contact thermometer and placed dataloggers). 
Following the fieldwork, a previous treatment of the thermographies using ThermaCAM Researcher Pro 2.10 was developed, applying the concepts of level and field with a colour palette to give meaning to the images (Fig. 4). The darker tones represent the lowest temperatures and the lighter ones the highest.

\section{Laser scanner survey}

In order to minimize effort, time and avoid occlusions gaps, it was necessary to plan the number of scans and their location previously. Also wall irregularities determined the position and the number of scans needed. For the ice cave, three scans were made from each of the walls, with placements at medium resolution and a full field of vision $\left(360^{\circ}\right.$ in horizontal and $270^{\circ}$ in vertical), all of which lasted 7.5 minutes.

Data were processed as follows:

1. Integration of the point clouds was done using the technique of target resection; a method involving the scanning of the same targets from different angles. The whole cloud comprised $76,178,580$ points (Fig. 5).

2. Cleaning and regularization of the cloud was achieved by noise elimination and the cloud regularized (Fig. 6).

Combination of laser scanner and thermographic survey

Once obtained, the panoramic thermography was imported using Leica Cyclone 7.3 (c) and co-registering each thermography with the scan by means of the marking of control points on the thermography and on the cloud of points. The correspondence between the thermographic images and the cloud of points was done looking for targets in the thermography and in the cloud of points as it was visualized on screen. The minimum number of points that need to assemble both technologies is 6 , with more points increasing the precision. Once the process was finished, the three-dimensional thermographic model was made (Lagüela et al., 2011).

\section{RESULTS AND DISCUSSION}

\section{D thermographic models}

The panoramic thermography consists of 8 thermographies and these were overlapped on the cloud of points using the control points (control targets) (see Fig. 4). It enabled a maximum error in thermography orientation of $1.0031 \mathrm{px}$, which is an acceptable error for a 307,200 px image (Lagüela et al., 2011).

From each of the thermographies obtained, quantitative information can be extracted (see Fig. 7), but always taking into account factors specific to the thermographed object and applicable in any case to the final orthothermography. The emissivity is a function of the element to thermograph. Is necessary to know moisture, atmospheric temperature, reflected temperature, and finally the distance in order to obtain reliable temperatures (see object parameters in Fig. 7).

\section{Orthothermographies}

Initially, a highly accurate three-dimensional model with the laser scanner is obtained. Next, superimposing the thermal image produces an orthoimage. The orthoimage is a transformed digital image showing the scene photographed in orthogonal projection (Lerma, 2002). The transformation of a photographic image in orthoimage represents the passage of a perspective projection to

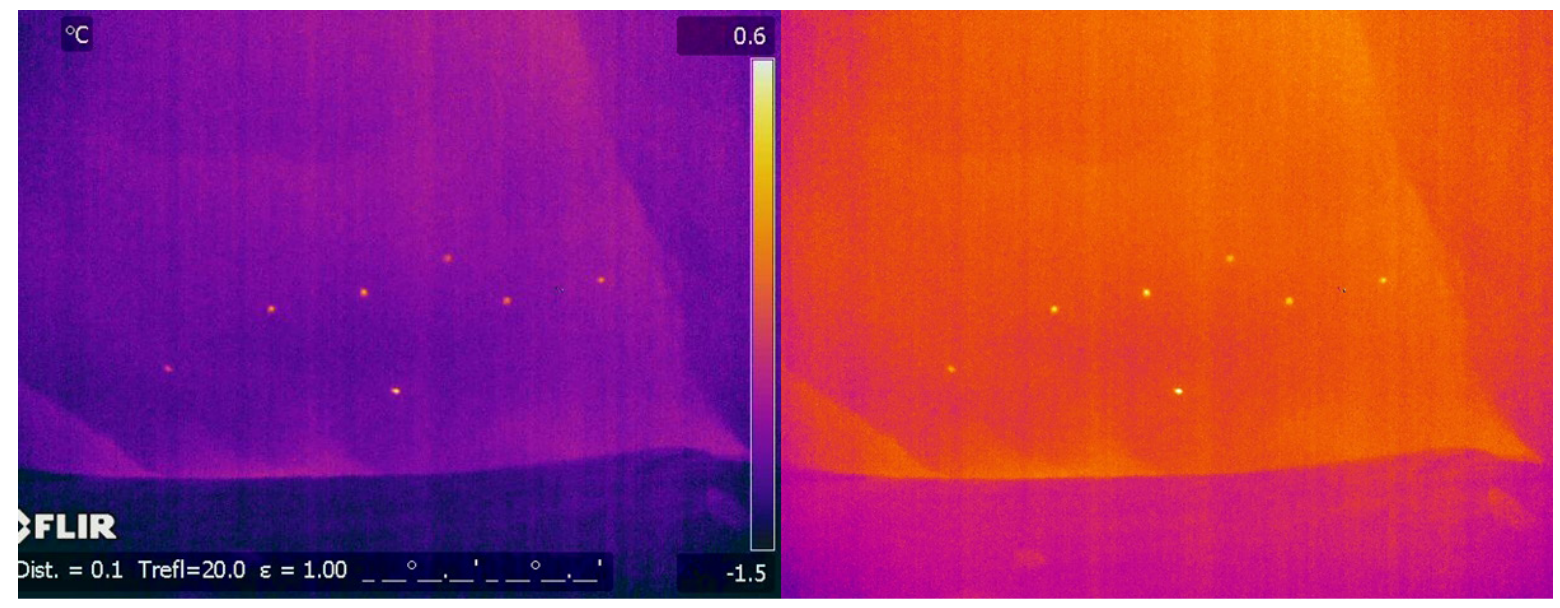

Fig. 4. Preparing thermographies to give them quantitative meaning using ThermalCAM Researcher Pro 2.10 software. Yellow dots are targets used to overlap panoramic thermography and the cloud of points.

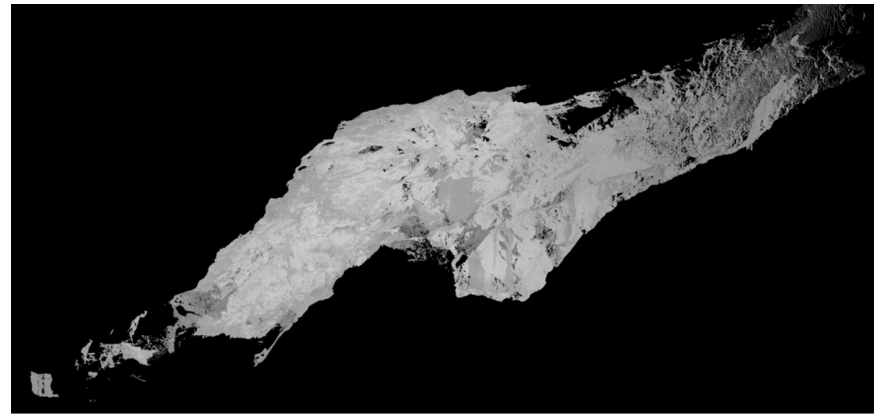

Fig. 5. Alignment point clouds uncleaned.

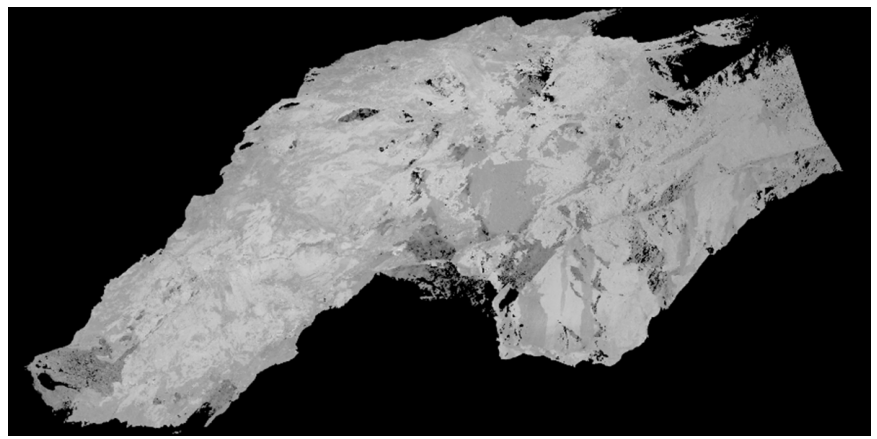

Fig. 6. Cleared point cloud ready for mesh generation. 

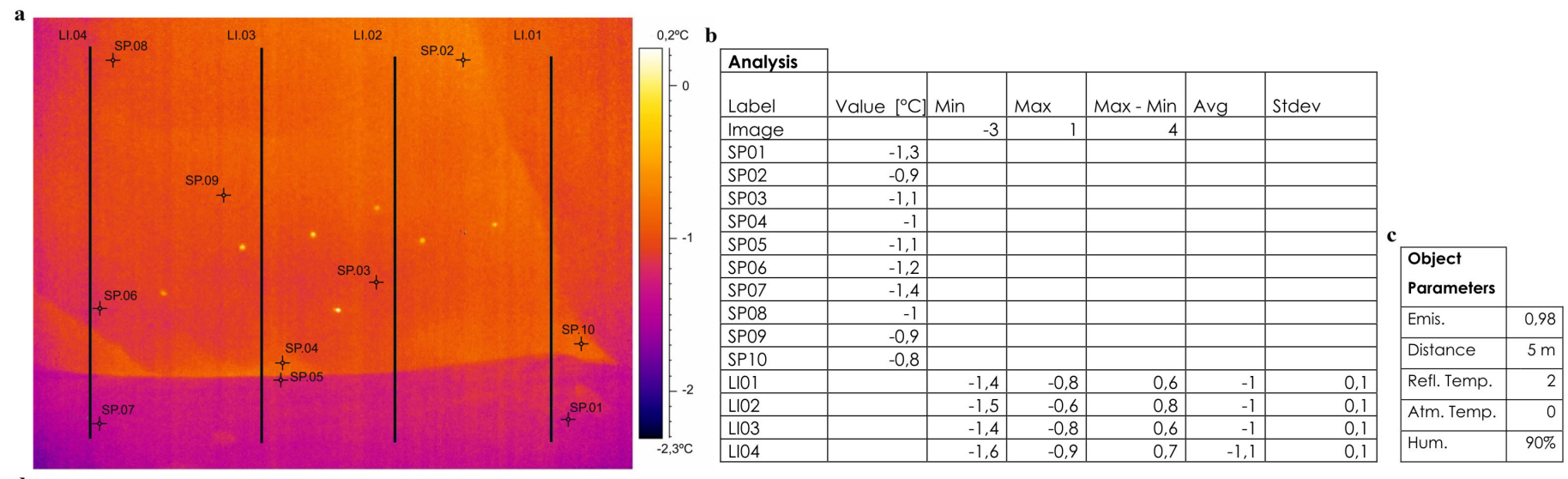

d
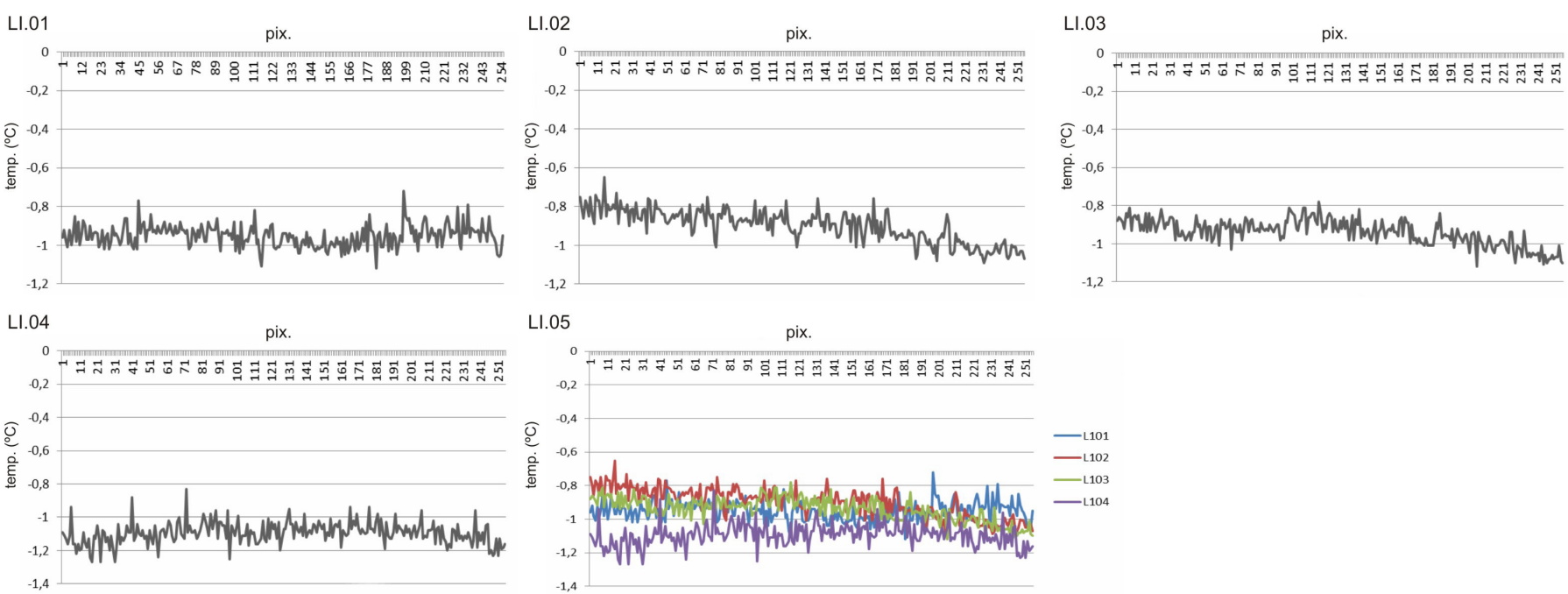

Fig. 7. Example of thermography analyzed and numerical parameters extracted from analysis: a) thermography with profiles (LI) and thermal points (SP); b) quantitative data from thermographic profiles and points; c) wall object parameters necessary for the final thermography treatment; d) thermal profiles from thermography.

orthographic projection. This process is called differential rectification. Differential rectification eliminates the image shift produced by the tilt of the photographic image and the orographic effect of the ground surface or object. The creation of orthoimages can be done in two possible ways: by direct or inverse projection (Novak, 1992).

In the differential rectification method of orthoimage generation, each pixel of the original image $(x, y)$ is projected upon the 3D surface of the model by means of the collinearity condition (based on the parameters of internal and external orientation) (Eq.1) to thus obtain the spatial coordinates $(X, Y, Z)$, which will later be projected onto the plain of the orthoimage. In the collinearity equation below

$$
\begin{aligned}
& x=x_{p p}-f \cdot \frac{r_{11}\left(X-X_{0}\right)+r_{12}\left(Y-Y_{0}\right)+r_{13}\left(Z-Z_{0}\right)}{r_{31}\left(X-X_{0}\right)+r_{32}\left(Y-Y_{0}\right)+r_{33}\left(Z-Z_{0}\right)} \\
& y=y_{p p}-f \cdot \frac{r_{21}\left(X-X_{0}\right)+r_{22}\left(Y-Y_{0}\right)+r_{23}\left(Z-Z_{0}\right)}{r_{31}\left(X-X_{0}\right)+r_{32}\left(Y-Y_{0}\right)+r_{33}\left(Z-Z_{0}\right)}
\end{aligned}
$$

$\mathrm{x}, \mathrm{y}=$ original image pixel coordinates; $\mathrm{X}_{\mathrm{pp},} \mathrm{y}_{\mathrm{pp}}=$ coordinates of the principal point; $\mathrm{f}=$ principal distance; $\mathrm{X}=$ object coordinates; $\mathrm{X}_{0}=$ projection center coordinates; $r_{11} r_{12 \ldots . . . .}=$ components of the rotation matrix; $r_{11}=\cos \varphi^{*} \cos \mathrm{K} ; \mathrm{r}_{12}=\cos \varphi^{*} \operatorname{sen} \mathrm{K} ; \mathrm{r}_{13}=-\operatorname{sen}$ $\varphi ; \mathrm{r}_{21}=\operatorname{sen} \varphi^{*} \operatorname{sen} \omega^{*} \cos \mathrm{K}-\operatorname{Cos} \omega^{*} \operatorname{sen} \mathrm{K} ; \mathrm{r}_{22}=\operatorname{sen} \varphi$ ${ }^{*} \operatorname{sen} \omega * \operatorname{sen} K+\cos \omega * \cos K ; r_{23}=\operatorname{sen} \omega * \cos \varphi ; r_{31}=$ $\operatorname{sen} \varphi * \cos \omega * \cos K+\operatorname{sen} \omega^{*} \operatorname{sen} K ; r_{32}=\operatorname{sen} \varphi * \cos \omega$ ${ }^{*} \operatorname{sen} \mathrm{K}-\operatorname{sen} \omega{ }^{*} \cos \mathrm{k} ; \mathrm{r}_{33}=\cos \omega{ }^{*} \cos \varphi(\omega=$ rotation angle on the $\mathrm{x}$-axis $(\mathrm{x}) ; \varphi=$ rotation angle on the $\mathrm{y}$-axis (y); $\mathrm{K}=$ rotation angle in three dimensions $(\mathrm{z})$. The digital image comprises an array of small rectangular elements (pixels). From each of the pixel sizes, their position in the image and the value associated in the grayscale is known. In digital images, it is clear that the pixel is the differential element to rectify, since it is the smallest unit of which it is composed. The process is done in batch mode, obtaining first the threedimensional digital model, proceeding then to realize the differential correction.

To carry out a differential correction process it is necessary to have a three-dimensional digital model stored in the same way than the image, e.g. with a raster structure from an elevations matrix. This model should be referred to a coordinate projection system in which the rectified image will be obtained.

The relationship between the orthogonal projection of the land and the conical projection of the picture is given by the collinearity equations. The purpose of the digital image correction is to assign the corresponding gray value to each of the matrix elements of the digital model.

Given that the morphology of the object is available with great precision and spatial resolution, corresponding to the 3D model provided by the TLS, true orthoimages have been obtained, in which the relief effect of the object is corrected. A true orthoimage generated from the TLS 3D model and thermal image is named orthothermography (Rodríguez-Gonzálvez et al., 2012) (Fig. 8). 

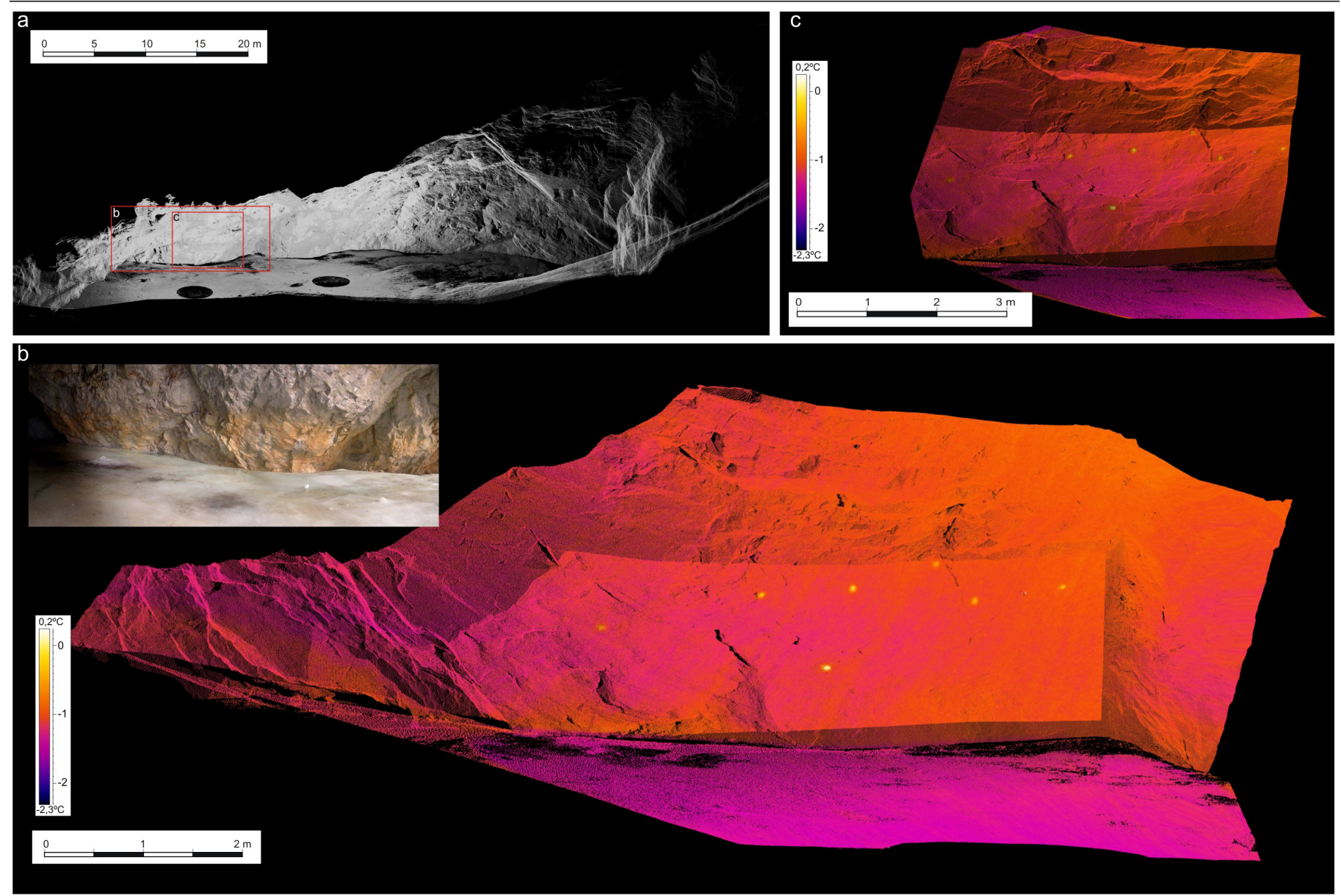

Fig.8. Peña Castil Ice Cave orthothermography: a) main orthoimage generate by rectification (in lower ice room); b) final orthothermography $(b=a+8$ thermographic images; example Fig.7a); c) detailed orthothermography. The yellow dots are the targets for resection process. Darker color tones represent the ice block temperatures and warm ones cave walls. Real image in photography.

\section{Potential uses in ice cave researches}

The combination of these two techniques for the thermal monitoring of the Peña Castil Ice Cave has some remarkable implications for ice cave research. Not only does it result in precise data of the volumes and surfaces of the ice block (improving traditional topographic techniques), but it also enables us to visualize thermal behaviour and current air flows in this type of cave.

The great versatility of the 3D model must be considered, enabling us to focus on certain aspects and dynamics of the ice block and the cave in general (for instance Figs. 1 and 9). In this case, it allows us to observe ice processes related to direct

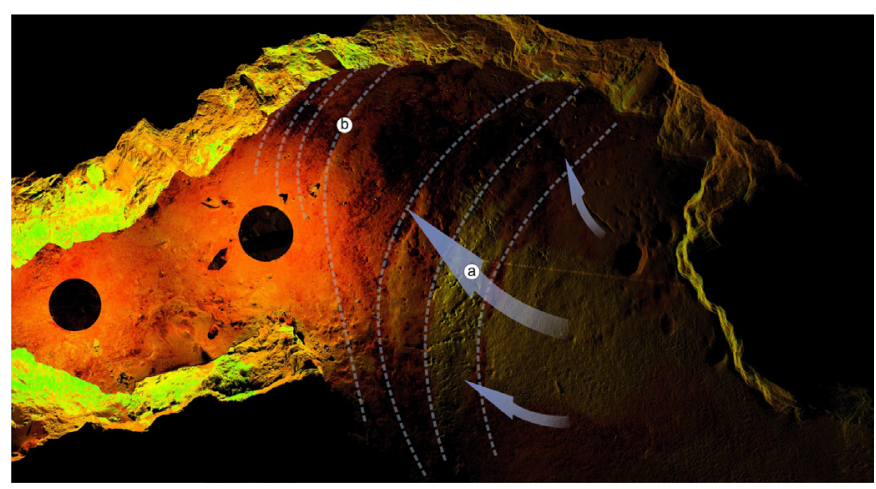

Fig. 9. Top view of the slope entrance. Snow inputs external (a) push and compress the ice block (b). The 3D models allow analyzing geomorphological process and morphologies non visible in fieldworks. Blue arrows indicate snow inputs; stripped blue lines indicate push arches in the snow zone and ice block. snow inputs, incorporated from topoclimatological external conditions which push the ice block, compress it and deform it, causing push arches. At least 3 push arches are observed in the snow slope, and 4 in the ice block. These push arches may be related to the arches observed in the middle of the ice block, in the lower room and under the first ice layers (Gómez-Lende \& Serrano, 2012b). These arches are similar to traction fissures and preserve the same orientation and angle as the push arches represented in Fig. 10. This may indicate a similar origin and a mechanical movement of the snow inputs and its influence on the dynamics and ice block evolution. In traditional topographical surveys it is very difficult to get accurate zenithal views as those provided by laser scanner.

Likewise, orthoimages extracted from the 3D model help us to estimate the approximate ice block volume (at least 33,000 $\mathrm{m}^{3}$ ) and more accurately the ice block surface $\left(629 \mathrm{~m}^{2}\right)$ (see Fig. 1). In making 3D models we might also estimate the total ice volume, calculating seasonal cryomorphology volumes observed in the ice cave at the end of open period (Gómez-Lende et al., 2011; Gómez-Lende \& Serrano 2012a, 2012b).

On the other hand, orthothermographies enable us to observe, although in only one field survey (carried out in November 2012; Figs. 7-10), graphic and quantitativ, vertical and horizontal thermal air mass characterization, as well as thermal gradients in cavern walls and their thermal differences in comparison to 

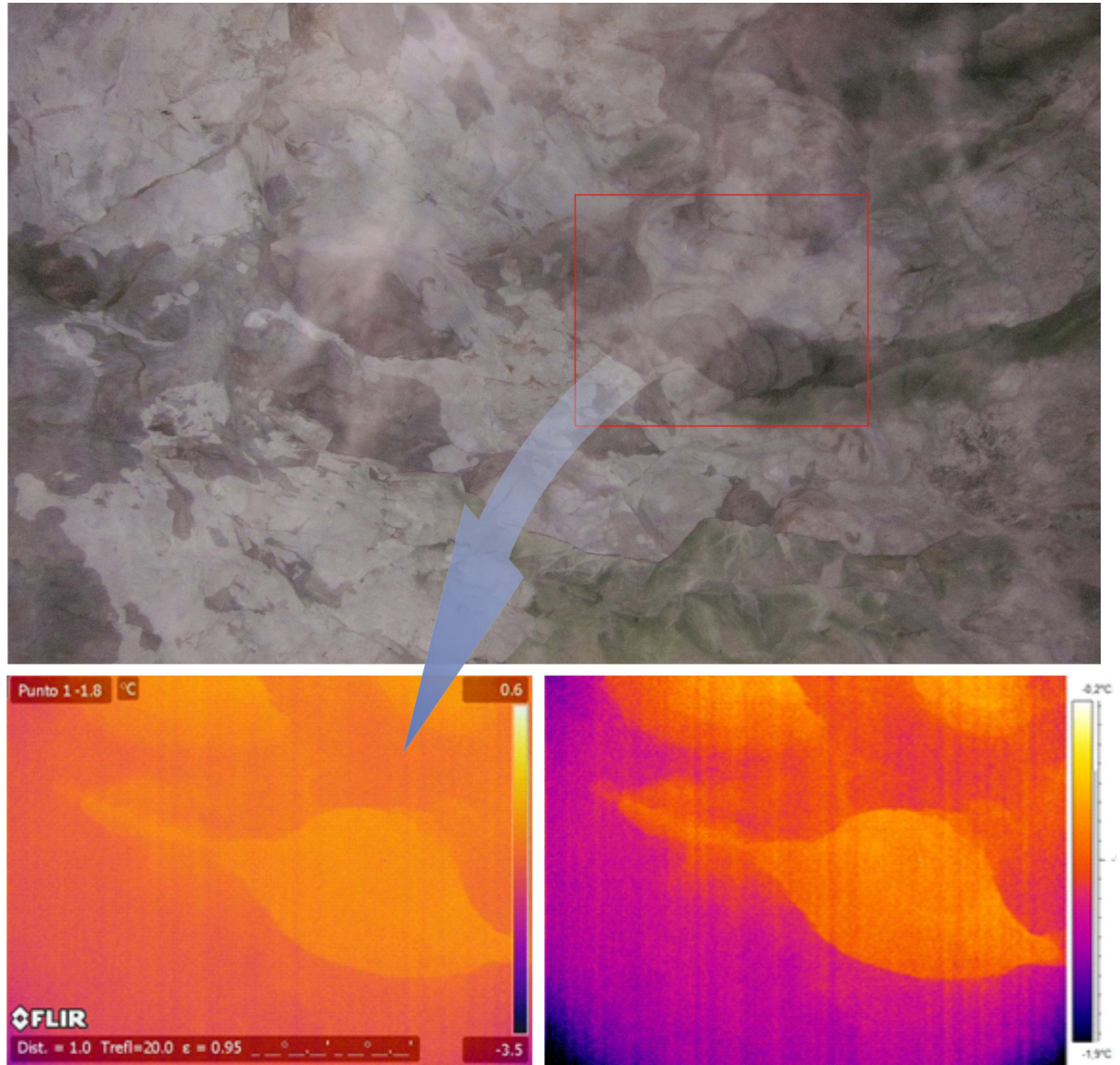

Fig. 10. Warm air masses in the cave roof detected with the thermographic camera. (a) original thermography taken during fieldwork; (b) final thermography after enhancement in ThermalCAM Researcher Pro 2.10 software. These air masses are stored in the cave roof where there is no exit to the outside.

the ice block. This is not possible to determine with traditional methods (thermal dataloggers).

As an example, Figure 8 shows a potential use of this method in this thermal characterization. It is possible to extract from an orthothermography several thermographical profiles (4 profiles in Fig. 7 ) as concrete thermal points (SP. in Fig. 7). Graphics and charts made from profiles (LI.01-LI.05 in Fig. 7) show at a glance, differences between the lower few metres of cave wall and the ice block surface, an average of $-1^{\circ} \mathrm{C}$ (range -0.6 to $-1.6^{\circ} \mathrm{C}$ ). Also it allows a representation of a thermal area, more useful than single data obtained with datalogger registers (dataloggers enable us only one data at a specific point), and it would allow to detect thermal and airflow in rock fissures, etc. In orthothermography examples (like Fig. 8b, 8c), profiles and thermography colours show a consistent decrease in temperature approaching the ice block surface (temperatures close to $-1.5^{\circ} \mathrm{C}$ ). In Fig. 7 , profiles LI.01 and LI.04 have a nonlinear trend caused probably by the irregularity of the wall. Also LI.04 profile shows a lower temperature because it is situated further into the cave and is thus less influenced by direct solar radiation (see also photo in Fig. 8). Nevertheless, LI.02 and LI.03 show a slight increasing trend and a difference with the ice block temperature. The little differences in the numerical charts extracted from the thermographic survey are more visible in the thermal image (Fig. 7a). In November, we could not observe a pronounced influence of the wavelength of cold from the ice block (as shown by the profiles); but it is possible that it will be observed in future surveys.

This technical combination of methods is useful to visualize the air and thermal flows inside the ice cave. The determination of the warm air masses in the different parts of the cavern is shown in Figure 10. The warm air masses remain stored in the ice cave roof in areas where there is no exit to the outside. These would be impossible to detect using dataloggers or traditional thermographical surveys.

\section{CONCLUSIONS}

a) The application of this type of techniques is precise and versatile, and so improves on traditional telemetries.

b) The marked topographic irregularities in this type of environment, important for the determination of the air circulation and energetic balances in ice caves, are recorded with precision using the 3D thermographic models.

c) Such instrumentation works perfectly independently of luminosity, which permits models to be made in underground environments in which details can be observed that otherwise go unnoticed in fieldwork. The vertical perspective of the model means that data can be obtained in a way that would be impossible to notice and quantify through direct observation and classical topography (e.g. flow arches in the snow ramp and ice block). 
d) The results permit multiple quantitative analyses to be obtained, both of the cave in general and of those aspects associated with ice caves: ice dynamics and morphologies, climatic parameters and evolution, and the behaviour of air and heat flows, often not considered in the study of this type of caves due to the difficulties of access and analysis.

e) The potential of these tools in the measurement of ice morphologies will provide an important source of knowledge concerning variations in surfaces, volumetrics and ice thicknesses both intrannually and interannually. It will become decisive in calculation of ice mass balance.

f) Without doubt, one of the greatest advances with the application of this type of technique (3D models and thermography) is that it is an important step forward for the quantitative knowledge of the energy balance of an ice cave, a fundamental factor in the evolution of an underground ice block.

Future studies focussing on introducing more depth and development of combined techniques may help to understand with greater precision the specific dynamics and processes of ice caves. A step forward would be undertaking fieldwork in different seasons and consecutive years in order to study variations in the different glacioclimatological periods (open and closed periods).

\section{ACKNOWLEDGEMENTS}

This research was funded by I+D Programme of the Ministry of Science and Innovation (project CGL-2010-19729) and the Ministry of Environment (OAPN-053/2010). We wish to thank CES Alfa and GELL (Grupo Espeleológico La Lastrilla), speleological associations, specially to Javier Sánchez, Emilio Herrera and Enrique Ogando.

\section{REFERENCES}

Bryan P.G., Corner I. \& Stevens D., 1999 - Digital rectification techniques for architectural and archaeological presentation. Photogrammetric Record, 16 (93): 399-415.

http://dx.doi.org/10.1111/0031-868X.00131

Buchroithner M.F. \& Gaisecker T., 2009 - Terrestrial Laser Scanning for the Visualization of a Complex Dome in an Extreme Alpine Cave System. Photogrammetrie Fernerkundung Geoinformation, 4: 329-339. http://dx.doi.org/10.1127/1432-8364/2009/0025

Canevese E.P., Tedeschi R., Forti P. \& Mora P., 2008a - The use of laser scanning techniques in extreme contexts: the case of Naica Caves (Chihuahua, Mexico). Geologia tecnica \& ambientale (Journal of technical \& environmental geology), 2: 19-37.

Cavanese E.P., Tedeschi R. \& Forti P., 2008b - The caves of Naica. Laser scanning in extreme underground environments. The American Surveyor, 6 (2): 3-10.

Canevese E.P., Tedeschi R., Forti P. \& Uccelli F., 2009 - Laser scanning use in cave contexts: the cases of Castellana and Santa Barbara (Italy) and Naica (Mexico). In: White W.B. (Ed.), Proceedings of the $15^{\text {th }}$ International Congress of Speleology, Kerrville (USA), 3, 2061-2067.

Canevese E.P., Forti P, Naseddu A., Ottelli L. \& Tedeschi R., 2011 - Laser scanning technology for the hypogean survey: the case of Santa Barbara karst system (Sardinia, Italy). Acta Carsologica, 40 (1): 65-77.
Ergun B., Sahin C., Baz I. \& Ustintas T., 2010 - A case study on the historical peninsula of Istanbul based on three-dimensional modeling by using photogrammetry and terrestrial laser scanning. Environmental Monitoring and Assessment, 165: 595-601. http://dx.doi.org/10.1007/s10661-009-0971-0

Gómez-Lende M., Serrano E. \& Berenguer-Sempere F., 2011 - Cuevas heladas en Picos de Europa. Primeros estudios en Verónica, Altaiz y Peña Castil. Karaitza, 19: $56-61$.

Gómez-Lende M. \& Serrano E., 2012a - First thermal, morphological and ice types studies in the Peña Castil Ice Cave (Picos de Europa, Cantabrian Mountains. Northern Spain). In: Turri S., Strini A. \& Tomasi F. (Eds.), Volume of abstracts, 5th International worshop on ice cave, 16-23 September 2012, Valsassina, Italy: 52-53.

Gómez-Lende M. \& Serrano E., 2012b - Morfologías, tipos de hielo y regímenes térmicos. Primeros estudios en la cueva helada de Peña Castil (Picos de Europa, Cordillera Cantábrica). In: González A. et al. (Eds.), Avances de la Geomorfología en España 2010-2012. Actas de la XII Reunión Nacional de Geomorfología, Santander, 17-20 September 2012: 613-616.

González Trueba J.J. \& Serrano E., 2010 - La nieve en los Picos de Europa: implicaciones geomorfológicas y ambientales. Cuadernos de Investigación Geográfica, 36 (2): 61-84.

Höfle B., Forbriger M., Siart C. \& Nowaczinski E., 2012 - Fusion of terrestrial LiDAR and tomographic mapping data for $3 D$ karst landform investigation. Geophysical Research Abstracts. EGU General Assembly 2012, 2227 April, 2012 Vienna, Austria, 6324.

Lagüela S., Martinez J., Armesto J. \& Arias P., 2011 Energy efficiency studies through $3 D$ laser scanning and thermographic technologies. Energy and buildings, 43: $1216-1221$.

Lerma García J.L., 2002 - Fotogrametría moderna: analitica y digital. Universidad Politécnica de Valencia, $550 \mathrm{p}$.

Luetscher M. \& Jeannin P.Y., 2004 - A process-based classification of alpine caves. Theoretical and Applied Karstology, 61-66.

Melgosa Revillas S., 2011 - Guía de la termografía infrarroja. Fundación de la Energía de la Comunidad de Madrid, Madrid, $188 \mathrm{p}$.

Milius J. \& Peters C., 2012 - Eisriesenwelt. From laser scanning to photorealistic $3 D$ model of the biggest ice cave on Earth. In: Jekel T., Car A., Strobl J. \& Griesebner G. (Eds.), GI Forum 2012: Geovisualisation, Society and Learning. Berlin/Offenbach: 513-523.

Novak K., 1992 - Rectification of digital imagery. Photogrammetric Engineering and Remote Sensing, 62: 339-344.

Rodríguez-Gonzálvez P., Herrero Pascual J. S., GonzálezAguilera D., Muñoz-Nieto Á. L., Mancera-Taboada J., Sánchez-Martin N., Hernández-López D., Felipe-García B., Moreno Hidalgo M. Á., 2012 - Aplicación de técnicas geomáticas al análisis y diagnóstico de patologías en el patrimonio arquitectónico. I Congreso Iberoamericano de Geomática y Ciencias de la Tierra, Madrid, 16 - 19 octubre 2012.

Roncat A., Dublyansky Y., Spötl C. \& Dorninger P., 2011a - Full 3D surveying of caves: a case study of Marchënhohle (Austria). In: Marschallinger R. \& Zobl F. (Eds.), IAMG Conference Salzburg 2011. Mathematical Geosciences at the Crossroads of Theory and Practice. Salzburg, Austria, $11 \mathrm{p}$. 
Roncat A., Dublyansky Y., Spötl C, Dorninger P. \& Pfeifer N., $2011 \mathrm{~b}$ - A full-3D laser-scan mapping of a hypogene cave: a morphogenetic study of Märchenhöhle, Austria. Geophysical Research Abstracts. EGU 2011, Vienna, 13, 14039.

Sánchez J., Jordá L., Serrano E., Gómez-Lende M. \& Hivert B., 2011 - Memoria de las exploraciones subterráneas. Macizo central de Picos de Europa, Camaleño-Cantabria. CES Alfa-AS Charentaise, inédito, $51 \mathrm{p}$.
Santos Delgado G., Martínez Rubio J., Silva Barroso P.G., Sánchez Moral S., Cañaveras Jiménez J.C. \& De la Rasilla Vives M., 2012 - Contribución al conocimiento de la cueva de El Sidrón (Piloña, Asturias) con técnicas de láser escáner 3D. In: González A. et al. (Eds.), Avances de la Geomorfología en España 2010-2012. Actas de la XII Reunión Nacional de Geomorfología, Santander, 17-20 September 2012: 255-258. 